231

Received: September 15, 2017

Accepted: December 7, 2017
Macedonian Journal of Animal Science, Vol. 7, No. 1-2, pp. 25-29 (2017)

ISSN $1857-6907$

e-ISSN $1857-7709$

UDC: 636.52/.58.09:[611.718:577.22

Original scientific paper

\title{
THE EFFECT OF GENOTYPE, REARING SYSTEM AND DURATION OF FATTENING ON PHYSICAL CHARACTERISTICS OF TIBIA IN BROILERS
}

\author{
Zdenka Škrbić, Miloš Lukić, Veselin Petričević, Vesna Krnjaja, Nikola Delić \\ Institute for Animal Husbandry, Belgrade, Serbia \\ zdskrbic@gmail.com
}

\begin{abstract}
The aim of the research was to investigate the effects of medium-growing broiler genotypes, age of broilers at slaughter and rearing system in non-conventional meat production on the physical characteristics of the tibia. The study was conducted on Redbro and Redbro Naked Neck chickens, which were reared in the free range system. The quality of tibia was tested on Redbro chickens in free range and extensive conditions in the closed facility, until 42 or 84 days of age. Physical characteristics of tibia: length, mass, cross sectional area of the diaphysis, breaking force and specific breaking force, were established after slaughtering of the sample of 12 broilers per treatment and separation of the left tibia from the skeleton. The studied chicken genotypes have not exerted significant effect on osteometrical and biomechanical characteristics of the tibia. The effect of rearing system is not statistically confirmed, but the potential for improving the quality parameters of the tibia in the rearing system with free range could be established. Duration of fattening period in extensive rearing system in the closed poultry house, as well as gender, have demonstrated a significant effect on the physical characteristics of the tibia.
\end{abstract}

Key words: broilers; tibia; medium-growing genotype; non-conventional production system

\section{ВЛИЈАНИЕ НА ГЕНОТИПОТ, СИСТЕМОТ НА ОДГЛЕДУВАЊЕ И ВРЕМЕТРАЕЊЕТО НА ГОЕЊЕ ВРЗ ФИЗИЧКИТЕ КАРАКТЕРИСТИКИ НА ТИБИЈАТА КАЈ БРОЈЛЕРИТЕ}

\begin{abstract}
Целта на истражувањето беше да се испитаат влијанијата на среднорастечките бројлерски генотипови, возраста на бројлерите за колење и системот на одгледување во неконвенционално производство на месо врз физичките карактеристики на тибијата. Студијата беше спроведена на генотипот Redbro и Redbro голошијанери, кои беа одгледани во слободен систем (free range). Квалитетот на тибијата беше тестиран кај пилињата одгледани во слободни и екстензивни услови во затворен објект до 42 и 84 дена, соодветно. Физичките карактеристики на тибијата: должина, маса, пресек на дијафизата, сила на кршење и специфична сила на кршење, беа утврдувани по колењето на примерокот од 12 бројлери по третман и одвојување на левата тибија од скелетот. Испитуваните генотипови на пилињата не покажале значителен ефект врз остеометриските и биомеханичките карактеристики на тибијата. Влијанието на системот за одгледување не е статистички потврдено, но беше утврден потенцијал за подобрување на параметрите за квалитет на тибијата во рамките на слободниот систем на одгледување. Значително влијание врз физичките карактеристики на тибијата покажаа времетраењето на периодот на гоење во екстензивниот систем на одгледување пилиња во затворен простор, како и полот,
\end{abstract}

Клучни зборови: бројлери; тибија; среднорастечки генотип; неконвенционален систем на производство

\section{INTRODUCTION}

Problems with the skeleton are usually related to the commercial broiler genotypes and their genetic predisposition for early rapid growth. The rapid development of muscle mass in the first two weeks of life of broilers is not accompanied by adequate development of the skeleton. The consequences of that, as well as conditions in intensive, commercial rearing systems, with a large density and minor physical activity of broiler chickens, lead to several leg problems (lameness, deformity, frac- 
tures) which influence the productivity and efficiency of production, the quality of the carcass at the slaughter and animal welfare (Sanotra et al. [10]; Bessei [1]; Škrbić et al. [13]). The results of comprehensive research of Knowles et al. [5] conducted on 176 commercial broiler flocks show that at the age of 40 days over $27.6 \%$ of broilers show locomotors problems and $3.3 \%$ were hardly able to walk.

Reducing the intensity of the early growth of broilers in order to reduce the incidence of leg problems can be achieved using the slower growing genotypes and less intensive growing conditions. This is corroborated by the results obtained by Vitorović et al. [17], who have established differences in morphometric and biomechanical parameters of tibiotarsus between broiler hybrids with different genetic potential for growth. Đukić-Stojčić and Bessei [2] have demonstrated that broiler chickens of reduced body mass show higher activity, thus confirming the importance of body weight for physical activity of broiler chickens. The influence of gender of chickens on the incidence of broken and deformed bones, as well as the gait score, Oviedo-Rondon et al. [8] associate with body mass. However, there are results indicating that the reduction in the rate of growth does not improve the quality of the bones (Leterrier et al. [6]) and that the leg problems mainly relate to the interaction of genetic, nutritional and management factors (Waldenstedt [18]).

The aim of the experiment was to examine the physical properties of the tibia of broilers in nonconventional production, as an effect of broiler genotype of moderate growth, rearing systems, i.e. duration of fattening. Together with the determined production parameters and the quality parameters of the carcass (Škrbić et al. [14]), the study of the quality of the tibia shall provide a more complete understanding of the production and qualitative indicators, as well as indicators of animal welfare in nonconventional chicken meat production.

\section{MATERIALS AND METHODS}

The study was conducted in several stages. In the first trial, the effects of genotype broilers moderate growth on the quality of the tibia were studied, using the Redbro Naked Neck and Redbro variety of chickens with feathers, reared in the system with the free range by the age of 84 days, according to the technology of Škrbić et al. [15]. The research was conducted on a total of 300 broiler chickens divided into two groups and 3 repetitions. Access to the free range/pasture was provided on a daily basis after the age of 42 days. In the second and third trial, the quality of the tibia was tested on Redbro variety of chickens with feathers. In the second trial, the effect of the rearing system was studied on total of 300 chickens divided into two groups. The first group of Redbro chickens was grown extensively in the poultry house and the other on the free range. The duration of the fattening period was 84 days. In the third trial, Redbro chickens were reared extensively in the poultry house by the age of 42 and 84 days. In each group there were 150 chickens, distributed in boxes, with 3 repetitions per group. The physical characteristics of the tibia: length, mass, cross-sectional area of the diaphysis, breaking force and the specific breaking force, were determined after slaughtering of the sample of 12 broilers per treatment, with the equal share of genders. After the separation of the left tibiae from the skeleton, the mass of the wet bone and the length from the proximal to the distal end of the bone were measured. Based on the measured outer diameter, anteroposterior and latero-medial, using the equation for the surface of an ellipse (Vitorović [16]) the cross sectional area of the diaphysis of the bone was calculated. Bone strength was determined by the direct method for the determination of the breaking force (Mašić et al. [7]). Specific breaking force was calculated as the ratio of breaking force and cross-sectional surface of the tibia diaphysis.

Statistical analysis was performed by analysis of variance One-way ANOVA using statistical software STATISTICA package, version 8, StatSoft, Inc. (www.statsoft.com [12]).

\section{RESULTS AND DISCUSSION}

The measured parameters of the tibia of Redbro and Redbro Naked Neck broiler chickens at the age of 84 days, are presented in Table 1.

The differences found between the properties of the tibia in the Naked Neck Redbro genotype and Redbro chickens with feather showed no statistical significance. Redbro chicks had greater length and mass of the tibia $(15.33 \mathrm{~cm} ; 38.11 \mathrm{~g}$ vs. $15.14 \mathrm{~cm}$; $34.51 \mathrm{~g}$ ), as well as the absolute and relative indicators of the tibia strength $\left(40.01 \mathrm{~kg} ; 0.65 \mathrm{~kg} / \mathrm{mm}^{2}\right.$ vs. $38.64 \mathrm{~kg} ; 0.62 \mathrm{~kg} / \mathrm{mm}^{2}$ ), while the cross sectional area of the tibia was greater in Redbro Naked Neck chickens $\left(63.01 \mathrm{~mm}^{2}\right.$ vs. $\left.61.96 \mathrm{~mm}^{2}\right)$. The lack of significant differences in body mass of Redbro and Redbro Naked Neck broilers (Škrbić et al. [14]) can 
be brought into connection with the lack of signifycant differences in the quality parameters of the tibia, which is in accordance with the determined unfavourable genetic correlations between leg health indicators and body mass of broilers (Kapell et al. [4]). A statistically significant effect of the gender was determined, wherein all the values except for the specific breaking force were higher for the male chickens. In contrast, in the study of Oviedo-Rondon et al. [8], problems with the legs are more pronounced in male chickens, based on the higher incidence of broken, deformed bones and poorer gait scores, compared to female chickens.

Data on the quality parameters of the tibia in Redbro chickens, depending on the studied rearing systems, are shown in Table 2.

Table 1

The properties of tibia in Redbro and Redbro Naked Neck broilers

\begin{tabular}{|c|c|c|c|c|c|c|c|c|c|c|}
\hline \multirow[t]{2}{*}{ Factors } & \multicolumn{2}{|c|}{$\begin{array}{l}\text { Length } \\
(\mathrm{cm})\end{array}$} & \multicolumn{2}{|c|}{$\begin{array}{l}\text { Mass } \\
(\mathrm{g})\end{array}$} & \multicolumn{2}{|c|}{$\begin{array}{l}\text { Cross-section surface } \\
\text { of the diaphysis }\left(\mathrm{mm}^{2}\right)\end{array}$} & \multicolumn{2}{|c|}{$\begin{array}{l}\text { Breaking force } \\
\qquad(\mathrm{kg})\end{array}$} & \multicolumn{2}{|c|}{$\begin{array}{l}\text { Specific breaking } \\
\text { force }\left(\mathrm{kg} / \mathrm{mm}^{2}\right)\end{array}$} \\
\hline & $\mathrm{x}$ & SD & $\mathrm{x}$ & SD & $\mathrm{x}$ & SD & $\mathrm{x}$ & SD & $\mathrm{x}$ & SD \\
\hline \multicolumn{11}{|c|}{ Genotype } \\
\hline $\mathrm{RB}$ & 15.33 & 1.38 & 38.11 & 11.37 & 61.96 & 14.53 & 40.01 & 9.93 & 0.65 & 0.10 \\
\hline RBNN & 15.14 & 1.93 & 34.51 & 9.29 & 63.01 & 11.02 & 38.64 & 7.91 & 0.62 & 0.10 \\
\hline \multicolumn{11}{|c|}{ Pol } \\
\hline M & 16.56 & 1.22 & 45.18 & 5.78 & 71.85 & 8.07 & 44.84 & 8.28 & 0.63 & 0.13 \\
\hline $\mathrm{F}$ & 13.91 & 0.59 & 27.43 & 4.18 & 53.12 & 8.75 & 33.81 & 5.22 & 0.64 & 0.07 \\
\hline \multicolumn{11}{|c|}{ Genotype $\times$ Gender } \\
\hline $\mathrm{RB} \times \mathrm{M}$ & 16.53 & 0.33 & 48.12 & 4.43 & 73.65 & 5.48 & 46.65 & 7.97 & 0.64 & 0.12 \\
\hline $\mathrm{RB} \times \mathrm{F}$ & 14.12 & 0.76 & 28.10 & 4.95 & 50.27 & 10.30 & 33.37 & 6.91 & 0.67 & 0.09 \\
\hline RBNN x M & 16.58 & 1.77 & 42.25 & 5.76 & 70.05 & 10.26 & 43.03 & 8.91 & 0.63 & 0.15 \\
\hline RBNN x F & 13.70 & 0.30 & 26.77 & 3.59 & 55.98 & 6.55 & 34.25 & 3.43 & 0.61 & 0.04 \\
\hline \multicolumn{11}{|c|}{ Significance } \\
\hline Genotype & \multicolumn{2}{|c|}{ ns } & \multicolumn{2}{|c|}{ ns } & \multicolumn{2}{|c|}{ ns } & \multicolumn{2}{|c|}{ ns } & \multicolumn{2}{|c|}{ ns } \\
\hline Gender & \multicolumn{2}{|c|}{$\mathrm{p}<0.01$} & \multicolumn{2}{|c|}{$\mathrm{p}<0.01$} & \multirow{2}{*}{\multicolumn{2}{|c|}{$\mathrm{p}<0.01$}} & & & \multicolumn{2}{|c|}{ ns } \\
\hline Genotype $\times$ Gender & \multicolumn{2}{|c|}{ ns } & \multicolumn{2}{|c|}{ ns } & & ns & \multicolumn{2}{|c|}{ ns } & \multicolumn{2}{|c|}{ ns } \\
\hline
\end{tabular}

RB - Redbro; RBNN - Redbro Naked Neck; M - male; F - female

Table 2

The impact of rearing system on physical properties of tibia

\begin{tabular}{|c|c|c|c|c|c|c|c|c|c|c|}
\hline \multirow[t]{2}{*}{ Factors } & \multicolumn{2}{|c|}{$\begin{array}{l}\text { Length } \\
(\mathrm{cm})\end{array}$} & \multicolumn{2}{|c|}{$\begin{array}{l}\text { Mass } \\
(\mathrm{g})\end{array}$} & \multicolumn{2}{|c|}{$\begin{array}{l}\text { Cross-section surface of } \\
\text { the diaphysis }\left(\mathrm{mm}^{2}\right)\end{array}$} & \multicolumn{2}{|c|}{$\begin{array}{c}\text { Breaking force } \\
(\mathrm{kg})\end{array}$} & \multicolumn{2}{|c|}{$\begin{array}{l}\text { Specific breaking } \\
\text { force }\left(\mathrm{kg} / \mathrm{mm}^{2}\right)\end{array}$} \\
\hline & $\mathrm{x}$ & SD & $\mathrm{x}$ & SD & $\mathrm{x}$ & $\mathrm{SD}$ & $\mathrm{x}$ & $\mathrm{SD}$ & $\mathrm{x}$ & $\mathrm{SD}$ \\
\hline \multicolumn{11}{|c|}{ Rearing system } \\
\hline EPH & 14.95 & 1.78 & 35.66 & 11.10 & 61.30 & 15.91 & 38.99 & 5.27 & 0.66 & 0.11 \\
\hline FR & 15.33 & 1.38 & 38.11 & 11.37 & 61.96 & 14.53 & 40.01 & 9.93 & 0.65 & 0.10 \\
\hline \multicolumn{11}{|c|}{ Gender } \\
\hline M & 16.37 & 1.12 & 46.43 & 6.26 & 73.36 & 10.52 & 44.80 & 5.97 & 0.62 & 0.11 \\
\hline $\mathrm{F}$ & 13.91 & 0.76 & 27.33 & 4.21 & 49.90 & 7.32 & 34.21 & 5.50 & 0.69 & 0.09 \\
\hline \multicolumn{11}{|c|}{ Rearing system $\times$ Gender } \\
\hline $\mathrm{EPH} \times \mathrm{M}$ & 16.20 & 1.61 & 44.75 & 7.74 & 73.07 & 14.60 & 42.94 & 2.57 & 0.60 & 0.10 \\
\hline $\mathrm{EPH} \times \mathrm{F}$ & 13.70 & 0.77 & 26.57 & 3.61 & 49.53 & 3.37 & 35.05 & 4.13 & 0.71 & 0.10 \\
\hline FR $x$ M & 16.53 & 0.33 & 48.12 & 4.43 & 73.65 & 5.48 & 46.65 & 7.97 & 0.64 & 0.12 \\
\hline FR $x$ F & 14.12 & 0.76 & 28.10 & 4.95 & 50.27 & 10.30 & 33.37 & 6.91 & 0.67 & 0.09 \\
\hline \multicolumn{11}{|c|}{ Significance } \\
\hline Rearing system & \multirow{2}{*}{\multicolumn{2}{|c|}{$\begin{array}{c}\mathrm{ns} \\
\mathrm{p}<0.01\end{array}$}} & \multirow{3}{*}{\multicolumn{2}{|c|}{$\begin{array}{c}\mathrm{ns} \\
\mathrm{p}<0.01 \\
\mathrm{~ns}\end{array}$}} & \multirow{3}{*}{\multicolumn{2}{|c|}{$\begin{array}{c}\mathrm{ns} \\
\mathrm{p}<0.01 \\
\mathrm{~ns}\end{array}$}} & \multirow{2}{*}{\multicolumn{2}{|c|}{$\begin{array}{c}\mathrm{ns} \\
\mathrm{p}<0.01\end{array}$}} & \multicolumn{2}{|c|}{ ns } \\
\hline & & & & & & & & & \multirow{2}{*}{\multicolumn{2}{|c|}{$\begin{array}{l}\mathrm{ns} \\
\mathrm{ns}\end{array}$}} \\
\hline Rearing system $\times$ Gender & \multicolumn{2}{|c|}{ ns } & & & & & \multicolumn{2}{|c|}{$\mathrm{ns}$} & & \\
\hline
\end{tabular}

$\mathrm{EPH}$ - extensive in poultry house; $\mathrm{FR}$ - free-range; $\mathrm{M}$ - male; $\mathrm{F}$ - female 
The chickens reared extensively in the poultry house had lower values for length, mass, cross section surface of the diaphysis and the breaking force of the tibia $\left(14.95 \mathrm{~cm} ; 35.66 \mathrm{~g} ; 61.30 \mathrm{~mm}^{2} ; 38.99\right.$ $\mathrm{kg} / \mathrm{mm}^{2}$ ) in comparison with free-range chickens $\left(15.33 \mathrm{~cm} ; 38.11 \mathrm{~g} ; 61.96 \mathrm{~mm}^{2} ; 40.01 \mathrm{~kg} / \mathrm{mm}^{2}\right)$. Identified differences in these parameters between the studied rearing systems were not statistically confirmed. The male chickens had significantly greater length, mass, surface of the cross-section and the absolute breaking force of the tibia relative to the females, however the relative indicator of the strength of the tibia was not under the significant influence of the chicken gender. The effect of the rearing system is based on a variety of conditions for the physical activity of broilers and, respectively, the impact on the quality of bones. A direct impact of physical inactivity on the development and firmness of the tibia is presented by Foutz et al. [3]. In their study, the immobilization of tibia for two weeks reduced the length of the shank by $58-85 \%$ and the strength of the tibia by $40 \%$ compared to the control group. Based on the presented results it can be concluded that favourable conditions for the physical activity of the free range system had no significant effect on the development of the tibia. Sherlock et al. [11] have inferred the importance of broiler genotype in semi-intensive rearing conditions for the quality of the bones and have concluded that the fast-growing broiler genotype does not increase their physical activity sufficiently in order to positively impact on the quality of the bone. This may be the explanation

Table 3

The impact of duration of fattening period in extensive rearing system in poultry house on physical properties of tibia

\begin{tabular}{|c|c|c|c|c|c|c|c|c|c|c|}
\hline \multirow[t]{2}{*}{ Factors } & \multicolumn{2}{|c|}{$\begin{array}{l}\text { Length } \\
(\mathrm{cm})\end{array}$} & \multicolumn{2}{|c|}{$\begin{array}{c}\text { Mass } \\
(\mathrm{g})\end{array}$} & \multicolumn{2}{|c|}{$\begin{array}{c}\text { Cross-section surface of } \\
\text { the diaphysis }\left(\mathrm{mm}^{2}\right)\end{array}$} & \multicolumn{2}{|c|}{$\begin{array}{l}\text { Breaking force } \\
(\mathrm{kg})\end{array}$} & \multicolumn{2}{|c|}{$\begin{array}{l}\text { Specific breaking } \\
\text { force }\left(\mathrm{kg} / \mathrm{mm}^{2}\right)\end{array}$} \\
\hline & $\mathrm{x}$ & $\mathrm{SD}$ & $\mathrm{x}$ & SD & $\mathrm{x}$ & $\mathrm{SD}$ & $\mathrm{x}$ & $\mathrm{SD}$ & $\mathrm{x}$ & $\mathrm{SD}$ \\
\hline \multicolumn{11}{|c|}{ Duration of fattening in EPH } \\
\hline 42 & 10.50 & 0.40 & 20.93 & 3.00 & 42.09 & 7.11 & 30.62 & 7.70 & 0.73 & 0.13 \\
\hline \multicolumn{11}{|c|}{$\begin{array}{r}11.10 \\
\text { Pol }\end{array}$} \\
\hline M & 13.44 & 3.09 & 33.73 & 12.68 & 59.95 & 17.16 & 38.99 & 6.07 & 0.68 & 0.13 \\
\hline $\mathrm{F}$ & 12.01 & 1.87 & 22.87 & 5.05 & 43.44 & 7.86 & 30.62 & 7.08 & 0.71 & 0.12 \\
\hline \multicolumn{11}{|c|}{ Duration of fattening $\times$ Gender } \\
\hline $42 \times M$ & $10.68^{\mathrm{C}}$ & 0.26 & $22.70^{\mathrm{B}}$ & 1.48 & 46.83 & 4.67 & 35.04 & 6.09 & 0.75 & 0.13 \\
\hline $42 \times \mathrm{F}$ & $10.31^{\mathrm{C}}$ & 0.44 & $19.17^{\mathrm{B}}$ & 3.18 & 37.35 & 5.95 & 26.19 & 6.80 & 0.70 & 0.14 \\
\hline $84 \times M$ & $16.20^{\mathrm{A}}$ & 1.61 & $44.75^{\mathrm{A}}$ & 7.74 & 73.07 & 14.60 & 42.94 & 2.57 & 0.60 & 0.10 \\
\hline $84 \times \mathrm{F}$ & $13.70^{\mathrm{B}}$ & 0.77 & $26.57^{\mathrm{B}}$ & 3.61 & 49.53 & 3.37 & 35.05 & 4.13 & 0.71 & 0.10 \\
\hline \multicolumn{11}{|c|}{ Significance } \\
\hline Duration of fattening & \multirow{2}{*}{\multicolumn{2}{|c|}{$\begin{array}{l}\mathrm{p}<0.01 \\
\mathrm{p}<0.01\end{array}$}} & \multicolumn{2}{|c|}{$\mathrm{p}<0.01$} & \multicolumn{2}{|c|}{$\mathrm{p}<0.01$} & \multicolumn{2}{|c|}{$\mathrm{p}<0.01$} & \multicolumn{2}{|c|}{$\mathrm{ns}$} \\
\hline Gender & & & $\mathrm{p}<$ & & & & & & & \\
\hline Duration of fattening $\times$ Gender & \multicolumn{2}{|c|}{$\mathrm{p}<0.01$} & \multicolumn{2}{|c|}{$\mathrm{p}<0.01$} & \multicolumn{2}{|c|}{ ns } & \multicolumn{2}{|c|}{$\mathrm{ns}$} & \multicolumn{2}{|c|}{$\mathrm{ns}$} \\
\hline
\end{tabular}

$\mathrm{EPH}$ - extensive in poultry house; $\mathrm{M}$ - male; $\mathrm{F}$ - female for our results, given that the Redbro chickens have moderate genetic potential for growth and can attain a body mass close to fast-growing broiler genotypes. Similarly, Özhan et al. [9] have found differences in mass, length and width of the tibia of broilers in the floor and cage rearing system, while reduced ash content in the cage system is explained by the reduced physical activity that leads to oxidative stress.

By prolonging the fattening period, Redbro chickens in extensive rearing system in the poultry house up to age at slaughter of 84 days increased significantly all absolute parameters of the tibia in relation to chickens at slaughter age of 42 days (Table 3). The relative indicator of the tibia strength was greater at the age of 42 days compared to 84 days $\left(0.73 \mathrm{~kg} / \mathrm{mm}^{2}\right.$ vs. $\left.0.66 \mathrm{~kg} / \mathrm{mm}^{2}\right)$, but without statistical confirmation of established difference. A significant effect of age of broilers on the physical activity, wherein the younger chickens were active than older (Sherlock et al. [11]), despite less load of bones by the body mass, are the reasons for the greater specific breaking force of the tibia at the age of 42 days compared to 84 days. A significant interaction effect of the duration of fattening and gender of chickens was determined on the tibia length and mass. The effect of gender on the length and mass of the tibia was not manifested at the age of 42 days, indicating the lack of maturity of the skeleton at this age, while at the age of 84 days, male chickens had significantly greater length and mass of the tibia. 


\section{CONCLUSION}

Based on the presented results, it can be concluded that osteometrical and biomechanical characteristics of the tibia were not under significant influence of studied broiler genotypes and implemented non-conventional rearing systems.

The lack of the impact of genotype is associated with a similar genetic potential of studied moderate growth broilers and achieved increase in body mass. The effect of rearing system was not fully manifested, although there was a tendency of better physical properties of the tibia in free-range conditions, which is associated with physical activity broilers.

By prolonging the fattening period of Redbro chickens in extensive rearing system in the poultry house, all absolute quality parameters of the tibia increased significantly. The relative strength indicator of the tibia had a tendency to decrease with the prolongation of the fattening period. Length and mass of the tibia were under significant interaction influence of the duration of fattening period and broiler gender.

Acknowledgment: This research is part of the Project EVB: TR-31033 financial supported by Ministry of Education, Science and Technological Development of the Republic of Serbia.

\section{REFERENCES}

[1] Bessei W.: Welfare of broilers: a review, World's Poultry Science Journal, Vol. 62, 455-466 (2006).

[2] Đukić-Stojčić M., Bessei W.: The effect of weight load on the legs of broilers behaviour. Biotechnology in Animal Husbandry, 27 (4), 1667-1671 (2011).

[3] Foutz T. L., Griffin A. K., Halper J. T., Rowland G. N.: Effects of increased physical activity on juvenile avian bone. Transactions of the ASABE, 50, 213-219 (2007).

[4] Kapell D.N.R.G., Hill W.G., Neeteson A.-M., Mcadam J., Koerhuis A.N.M., Avendańo S.: Twenty-five years of selection for improved leg health in purebred broiler lines and underlying genetic parameters. Poultry Science 91, 3032-3043 (2012)

[5] Knowles T. G., Kestin S. C., Haslam S. M., Brown S. N., Green L. E., Butterworth A., Pope S. J., Dirk Pfeiffer D.,
Nicolet C. J.: Leg Disorders in Broiler Chickens: Prevalence, Risk Factors and Prevention. PLoS ONE 3 (2), e1545 (2008). DOI:10.1371/journal.pone.0001545

[6] Leterrier C., Rose N., Constantin P., Nys, Y.: Reducing growth rate of broiler chickens with a low energy diet does not improve cortical bone quality. British Poultry Science, 39, 24-30 (1998).

[7] Mašić B., Antonijević N., Vitorović D., Pavlovski Z., Milošević N., Jastšenjski S.: Prilog određivanju čvrstoće kostiju pilića. Peradarstvo, 8-9, 19-24 (1985).

[8] Oviedo-Rondón E. O., Wineland M. J., Funderburk S., Small J., Cutchin H., Mann M.: Incubation conditions affect leg health in large, high-yield broilers. Journal of Applied Poultry Research, 18, 640-646 (2009).

[9] Özhan N., Şimşek Ü. G., Özçelik M.: Comparison of floor and cage housing systems in terms of some welfare assessments in broiler. Ankara Üniversitesi Veteriner Fakultesi Dergisi, 63, 3, 317-322 (2016).

[10] Sanotra G. S., Lund J. D., Ersboll A. K., Petersen J. S., Vestergaard K. S: Monitoring leg problems in broilers: A survey of commercial broiler production in Denmark. Worlds Poultry Science Journal, Vol. 57, 55-69 (2001).

[11] Sherlock L., Demmers T., Goodship A., McCarthy I.,Wathes C. H.: The relationship between physical activity and leg health in the broiler chicken. British Poultry Science, 51 (01), 22-30 (2010).

[12] StatSoft Inc. Statistica (data analysis software system). 2007. version 8.0 www.statsoft.com.

[13] Škrbić Z., Pavlovski Z., Lukić M.: Stocking Density - Factor of Production Performance, Quality And Broiler Welfare. 9th International Symposium "Modern Trends in Livestock Production", October 2009, Belgrade. Biotechnology in Animal Husbandry, 25, 5-6, Book 1, 359-373 (2009).

[14] Škrbić Z., Pavlovski Z., Lukić M., Petričević V.: Production performance and carcass quality of coloured broilers differentiated genetic potencial for growth. Biotechnology in Animal Husbandry, 29 (4), 615-624 (2013).

[15] Škrbić Z., Pavlovski Z., Lukić M., Tomašević D.: Tehnologija proizvodnje pilećeg mesa u sistemu gajenja sa ispustom. Biotechnology in Animal Husbandry, 26, spec issue, 67-81 (2010)

[16[ Vitorović D.: Anatomske karakteristike kostiju i mišića pilića lakog i teškog tipa gajenih na podu i u kavezima. Doktorska disertacija. Veterinarski fakultet, Beograd, 1992.

[17] Vitorović D., Pavlovski Z., Škrbić Z., Lukić M., Petričević V.: Morphometric and biomechanical parameters of tibiotarsus in different strains of broilers. Biotechnology in Animal Husbandry, 24 (5-6), 53-59 (2008).

[18] Waldenstedt L.: Nutritional factors of importance for optimal leg health in broilers: A review. Animal Feed Science and Technology, 126, 291-307 (2006). 
